\title{
Visible Minority Women in German Politics: Between Discrimination and Targeted Recruitment
}

\author{
Anne Jenichen, Aston University, Birmingham, UK, Email: a.jenichen@aston.ac.uk \\ Accepted for publication by German Politics.
}

\begin{abstract}
By focusing on visible minority women in Germany, this article contributes to an emerging field of intersectional research on political representation. Research on minority women's access to politics is still limited despite Germany's sizable immigrant population. To fill this gap, this article provides recent data on the descriptive representation of visible minority women at both the federal and state level. Furthermore, it seeks to explain differences in political representation, primarily why the representation of minority women at the federal level and in some states is better than that of minority men, while in other states it is the reverse. Since traditional institutional explanations, such as gender quotas and electoral systems, provide only part of the solution to this intersectional puzzle, this article argues that informal practices of individual party elites need to be considered. Qualitative interviews with visible minority women in German politics suggest that some party elites actively promote minority women, while others overlook or even discriminate against them, contributing an additional explanation of why minority women's access to politics is easier in some cases than in others.
\end{abstract}

Keywords: political representation, intersectionality, gender, migration background, German politics 


\section{Introduction}

Germany has a large immigrant population, with more than $23 \%$ of the population now having a migration background, ${ }^{1}$ yet research on the access of minority women to politics is limited. Existing research consists primarily of studies on the political representation of immigrants that also applies a gender perspective. Reiterating similar findings in other countries of Europe (e.g., Celis et al. 2014; Freidenwall 2016; Murray 2016), some studies suggest that minority women benefit from having a 'multiple advantage' as women and minorities (Mügge and Erzeel 2016) and, therefore, are better represented at national and regional levels than migrant men (Markowis 2015; Wüst 2014). Although the better representation of migrant women has been refuted for the local level (Hossain et al. 2016) and despite occasional mentioning of variation in how well migrant women are represented in German federal states (e.g., Donovan 2013, 35) and European countries (Fernandes et al. 2016, 5), systematic investigations of this variation are still scarce. ${ }^{2}$ The German federal system is a fascinating laboratory to study this variation because it allows for the isolation of cultural and institutional differences, thereby enabling a deeper understanding of why either minority women or men are better represented in politics. To this end, this article provides the latest data on the descriptive representation of visible minority women at both the federal and state levels. Based on the analysis of election data and qualitative interviews, it demonstrates and seeks to explain variation in the representation of minority women in German politics. The analysis reveals that approaches usually employed to explain the political representation of women and immigrants, such as gender quotas and electoral systems, have only limited explanatory power for this variation. Instead, qualitative

\footnotetext{
${ }^{1}$ Migration background is the official term used in Germany to denote first- and second-generation immigrants, which includes non-German nationals residing in Germany, foreign-born Germans as well as German nationals of whom at least one parent is either foreign-born or a foreign national. A bit more than half of them possess German citizenship (Statistisches Bundesamt 2018, 18, 34f).

${ }^{2}$ The only exception is Hughes (2016), who explains variation between the legislative representation of Muslim ethnic minority women in Western democracies with differences between majority and representative electoral systems.
} 
interviews with female politicians from a visible migration background suggest an alternative explanation: informal practices of individual party elites. Depending on their attitudes and preferences, party elites either discriminate against minority women as (younger) women and immigrants or deliberately recruit and support them to increase diversity and equality within their parties. While targeted recruitment and support are important aspects in the political careers of most women irrespective of migration background (Davidson-Schmich 2016; Markowis 2015, 127-9), not all women face the same levels of discrimination. The idiosyncratic - and rather arbitrary - practices of individual party elites at different levels help explain why some minority women benefit from the 'elevator effect' of gender quotas (Davidson-Schmich 2016) or from the 'multiple advantage' more than others.

In the following analysis, I focus on a subset of women within the group of politicians with a migration background, namely women from a non-European background whose immigration status is visible due to their name or appearance. Thus, this study represents an important deviation from most research on political representation in Germany, which usually combines immigrants of European and non-European origin (except for Donovan 2013). Grouping all immigrants is problematic because, at best, it incorrectly implies that all citizens with a migration background are subject to similar dynamics of discrimination. At worst, it makes racial discrimination invisible. The concept of race is a taboo in the German context due to its appropriation by the Nazi regime. However, as Mügge et al. emphasise, 'key dimensions of power relations go under-analysed by the omission of race' $(2018,20)$. Therefore, rather than reiterating the well-rehearsed focus in German research on migration background, I draw here 
on the Canadian concept of the visible minority ${ }^{3}$, which focuses on visible markers of difference and therefore allows for a consideration of racial discrimination. ${ }^{4}$

The article is divided into three parts: The first part outlines the theoretical framework of the study, followed by some information on methodology. The second part gives an overview of the descriptive representation of visible minority women in German politics at the federal and state levels. The final part assesses the explanatory power of institutional and alternative approaches.

\section{Theoretical framework}

This analysis draws on the concept of intersectionality (Hancock 2007; Weldon 2006) to explore how women's visible minority status shapes their access to German politics. An important question in intersectional research on political representation and recruitment is how gender and racial discrimination interact. That is, whether they lead to a 'double jeopardy' and thus exclusion due to the discrimination of minority women as women and as visible minorities, or whether minority women also may benefit from a 'multiple advantage' if their dual identities lead to less negative racial stereotyping and fit the vote-seeking strategies of parties (Mügge and Erzeel 2016). To address the question of why visible minority women in German politics sometimes (e.g., in some German states) benefit more from such a 'multiple advantage' than in others, I review several possible explanations found in the literature on the

\footnotetext{
3 'The Employment Equity Act defines visible minorities as "persons, other than Aboriginal peoples, who are non-Caucasian in race or non-white in colour"' (https://www12.statcan.gc.ca/censusrecensement/2016/ref/dict/pop127-eng.cfm).

${ }^{4}$ Using this approach, however, excludes white women from other European countries (Turkey is here defined as a non-European country), despite their often foreign-sounding names, as well as ethnic Germans from former Soviet states because their immigration status usually is not visible (they are white and have German-sounding names). Discrimination against these groups notwithstanding, it can reasonably be assumed that they face less discrimination than politicians with a visible, non-European migration background, which is why they are excluded from the analysis. The same applies to politicians with a non-European migration background which, however, is not visible and therefore not perceived by others, because it can reasonably be assumed that this precludes racial discrimination.
} 
political representation of women and minorities: institutional rules, such as gender quotas and electoral systems; party politics and demographics; and informal practices.

Institutional rules, such as gender quotas and electoral systems, affect how political parties select candidates and, thus, the opportunities of women and immigrants to achieve political office (Bloemraad and Schönwälder 2013; Norris 2006; Paxton et al. 2007). The most effective instruments to increase the number of women and minorities in parliaments are gender and ethnic quotas (Bird 2014; Krook 2010). Comparative research has shown, though, that minority women rarely benefit from separate gender or ethnic quotas unless these quotas are systematically combined. Otherwise, gender quotas primarily benefit majority women and ethnic quotas minority men (Bird 2016; Hughes 2011). Germany neither has legislated gender nor ethnic quotas. However, voluntary gender quotas do exist in most parties. As will be demonstrated later, visible minority women do benefit from these gender quotas, demonstrating that when combined with party strategies and ideologies supportive of ethnic diversity, 'equality and diversity can sit in tandem even when quotas do not' (Murray 2016, 595; see also Celis et al. 2014).

Electoral systems also have a bearing on the representation of women and visible minorities. As demonstrated by previous research (Hughes 2016; Paxton et al. 2007; Schönwälder 2013), women and visible minorities have better chances to be elected in proportional representation systems than in majority systems, 'because in list systems, party leaderships may be interested in compiling a list of candidates that represents the diversity of the population and thus be prepared or even actively motivated to place women - or immigrants - on these lists' (Schönwälder 2013, 643). In majority systems, by contrast, local party elites do have less incentive to contribute to the overall representation of the diversity of the electorate. As Schönwälder (2013) points out, party leaders 'want to field candidates who can win the seat. If they anticipate a negative voter response to a female or immigrant candidate, they may refrain 
from nominating such candidates' (643). Most German states use the same electoral system as the national level does. However, some differences exist whose explanatory power for the variation in visible minority women's representation will be assessed below.

In addition to institutional differences, political and demographic dissimilarities may explain variation as well. Centre-left parties, not only in Germany, are traditionally more supportive of gender equality and gender quotas (Davidson-Schmich 2016; Lang 2015) as well as liberal immigration laws and multiculturalism (Green 2004; Wüst 2016). Therefore, it could be expected that the representation of minority women was better in states (and during legislative periods) with a higher share of centre-left parties (i.e., the Social Democratic Party of Germany [SPD], the Greens and the Left), than centre-right parties (the Christian Democrats [CDU/CSU] and the Free Democratic Party of Germany [FDP]).

Another possible explanation is demographics. Previous research suggests that immigrants are better represented in electoral districts with a higher concentration of immigrants (Hossain et al. 2016; Geese and Schacht 2019). The question remains whether this also influences the representation of visible minority women. That is, whether an increase in the number of visible minority women recruited by parties results from a larger pool of potential minority candidates or whether gender discrimination in high ethnic concentration communities results in better chances for visible minority men rather than women.

As will be demonstrated later, the main explanation my analysis offers refers to informal practices within parties. As Bjarnegård and Kenny $(2016,382)$ emphasise, political recruitment is not only shaped by formal rules, '[i]nstead, informal networks of encouragement and recruitment often matter a great deal.' Most political careers start because aspirants are encouraged and recruited by party elites or party activists. These networks often favour homosociality, recruiting candidates of the same sex (usually men due to male dominance in parties) and constructing women and visible minorities as outsiders, which explains the 
continuous political overrepresentation of white, non-minority men (Bjarnegård 2013; see also Bird, Saalfeld and Wüst 2011, 13f.; Bloemraad and Schönwälder 2013, 567ff.). However, as Celis and Erzeel (2017) stressed, based on their research in Belgium, party elites are also often interested in maximising the representativeness of their party lists, which is why they deliberately nominate women and immigrants.

Consequently, the demand by party elites for specific types of candidates can disadvantage groups like visible minority women if intraparty decision-makers - primarily male and nonimmigrant - discriminate against them when nominating candidates. If gender and racial discrimination concur in such a way, they generate a 'double jeopardy' for these politicians as women and as visible minorities. However, the demand by party elites can also give rise to a 'multiple advantage' if visible minority women are particularly supported by party elites to demonstrate the diversity of the party (Mügge and Erzeel 2016). As will be shown below, the personal experiences of the interviewed female minority politicians in Germany suggest that party elites differ in how interested they are in promoting minority women. While some are supportive and actively promote minority women, others overlook and discriminate. Even though variation in support from political elites is not the only factor, it is an important reason why the political representation of minority women varies.

\section{Methodology}

The following analysis is based on the collection of primary data from the websites of the national parliament of the Federal Republic of Germany (Bundestag) and all 16 state parliaments for the past three elections (cut-off date 1 March 2019). To assess the role of the gender quota, I analysed candidate lists of all parties that obtained mandates after the 2017 general elections, based on the complete list of candidates provided by the Federal Returning Officer (Bundeswahlleiter 2017). To explore the correlation of party politics, on the one hand, 
and demographics, on the other hand, with the descriptive political representation of visible minority women, I used a simple linear regression based on data on electoral systems and election results retrieved from the database 'Wahlen, Wahlrecht und Wahlsysteme' [Elections, Voting Rights and Voting Systems] (www.wahlrecht.de) and on recent data on demographics from the Federal Statistical Office (www.destatis.de).

This data is complemented by qualitative interviews with thirteen female politicians conducted in February and April 2018, primarily from a Turkish background (except for one), to receive first-hand knowledge about determinants of political careers of visible minority women in German politics. The female politicians represent different German parties (two the Christian Democratic Union (CDU), four the SPD, five the Greens and two the Left) and, except for one, have held political office at the municipal, state or federal level. Their terms in office range from less than two to over ten years. Ten of them ran for office during the 2017 general elections, three of them succeeded in reaching a national mandate, and one as a successor. ${ }^{5}$ The interviews used a narrative approach, asking the interviewees to narrate their political biography with a special focus on opportunities and obstacles. This approach allowed the interviewer to conclude which experiences the politicians themselves perceived as significant. After the biographical narrative, I probed further on issues that had not been touched upon but are considered essential in political careers, including the role of the family and of socialisation, sources of political ambition, and experiences within political parties and during election campaigns.

Findings of qualitative interviews, of course, are not representative. They allow, however, for a richer understanding of determinants that shape the access of female visible-minority

\footnotetext{
${ }^{5}$ No more detailed information on their background can be provided here, because, due to the small numbers of female visible minority politicians in Germany, this may compromise the promised anonymity.
} 
politicians to political office gleaned from their personal experiences of discrimination and targeted recruitment.

\section{Descriptive political representation of visible minority women in Germany}

The descriptive representation of women in the German Bundestag has continuously increased from below 10\% from the 1950s till 1980s to a historic high of 36.5\% in 2013 (Markowis 2015, 215). Directly after the general elections in 2017 , the share dropped to $30.9 \%^{6}$ and, due to some female successors for retired deputies, slightly increased again to $31.1 \%$ by the time of data collection (March 2019). A similar increase to about one-third of women, on average $31.6 \%$ and $27.1 \%$, respectively, can also be observed in the German state parliaments and local councils (BMFSFJ 2017, 8-11).

Of the female members of the Bundestag, 5.86\% are from a visible, non-European minority. In the German state parliaments, the average share of visible minority women among all female deputies is, at $3.75 \%$, a bit lower, ranging from zero in all eastern German area states and the Saarland (due to the absence of visible minorities in their state parliaments in general), as well as Lower Saxony (where at the time of data collection all three visible minority deputies were men), to around $10 \%$ in the German city-states Hamburg (8.7\%), Berlin (9.43\%) and Bremen (12.9\%), as well as $13.64 \%$ in Schleswig-Holstein (table 1). At both the federal and state levels, almost all these women represent the centre-left parties (SPD: 14; Greens: 13; Left: 6), whereas only one visible minority woman is from the CDU and none from the liberal FDP or right-wing Alternative for Germany (AfD), confirming previous findings on the distribution of immigrantorigin representatives between parties as well as German states (Schönwälder 2013, 639). ${ }^{7}$

\footnotetext{
${ }^{6}$ See website of the German Bundestag: https://www.bundestag.de/abgeordnete/biografien/mdb_zahlen_19/frauen_maenner/529508 (last access: 28 January 2019).

${ }^{7}$ The full sample indicates highest shares of visible minorities in the state parliaments of Bremen (18.1\%), Hamburg (9.9\%) and Berlin (5.6\%); and also male visible minority deputies primarily represent the centre-left parties, but with slightly higher numbers for the CDU (4) and FDP (2).
} 
As a consequence of the German guest worker programme from the 1950s to 1970s, the largest immigrant group in Germany is of Turkish origin (Statistisches Bundesamt 2018, 127). Accordingly, more than three-quarters of the female and male non-European, visible minority representatives in the Bundestag and state parliaments are of a Turkish background. Other country backgrounds seen in the Bundestag include primarily Iran and Egypt, as well as Mali, Morocco, Pakistan, Palestine, Senegal and Yemen. Non-Muslim-majority countries of origin include the Democratic Republic of the Congo, Ghana and Kenya. ${ }^{8}$

Table 1 Share of all women and of visible minority women among them in German parliaments (March 2019)

\begin{tabular}{|c|c|c|}
\hline & $\begin{array}{c}\text { Share of all women in } \\
\text { parliament }(\%)\end{array}$ & $\begin{array}{l}\text { Share of visible minorities } \\
\text { among all female deputies } \\
\text { (\% and absolute number) }\end{array}$ \\
\hline Bundestag & 31.31 & $5.86(13)$ \\
\hline State parliaments & 31.34 & $3.75(22)$ \\
\hline Lower Saxony & 30.66 & $0.00 \quad(0)$ \\
\hline Brandenburg & 39.77 & $0.00 \quad(0)$ \\
\hline Mecklenburg-Hither Pomerania & 25.35 & $0.00 \quad(0)$ \\
\hline Saxony & 33.33 & $0.00 \quad(0)$ \\
\hline Saxony-Anhalt & 21.84 & $0.00 \quad(0)$ \\
\hline Thuringia & 41.76 & $0.00 \quad(0)$ \\
\hline Saarland & 33.33 & $0.00 \quad(0)$ \\
\hline Bavaria & 26.83 & $1.82 \quad(1)$ \\
\hline North Rhine-Westphalia & 26.63 & $1.89 \quad(1)$ \\
\hline Hessen & 33.58 & $2.17 \quad(1)$ \\
\hline Rhineland-Palatinate & 31.68 & $3.13 \quad(1)$ \\
\hline Baden-Wuerttemberg & 26.57 & $5.26 \quad(2)$ \\
\hline Berlin & 33.13 & $9.43 \quad(5)$ \\
\hline Hamburg & 38.02 & $8.70 \quad(4)$ \\
\hline Bremen & 37.35 & $12.90 \quad(4)$ \\
\hline Schleswig-Holstein & 30.14 & $13.64 \quad(3)$ \\
\hline
\end{tabular}

Sources: Websites of the federal and 16 state parliaments (accessed: 1 March 2019).

Previous research suggests that women of immigrant origin are better represented in German parliaments than immigrant men and non-immigrant women (Markowis 2015; Schönwälder 2010; Schönwälder et al. 2011; Wüst 2014, 8). ${ }^{9}$ My research, however, confirms this

\footnotetext{
${ }^{8}$ There is one member of a state parliament whose ancestors are from Brazil, but since he is already of the fifth generation, I did not include him as a visible minority in the sample, despite foreign-sounding name.

${ }^{9}$ This view, however, is contested by Hossain et al. $(2016,106)$ who have demonstrated for the municipal level that, if considering their share in the overall population, immigrant women are less well represented than immigrant men and non-immigrant women.
} 
expectation only partially. It can be confirmed for the national level where the majority of visible minority representatives are women $(59.1 \%$, compared to $30.4 \%$ of women in the group of the rest of deputies). Nevertheless, when adding information on the federal states and a historical perspective, variation emerges. While in the states of Schleswig-Holstein, RhinelandPalatinate, Baden-Wuerttemberg and Berlin the majority of visible minority deputies are women, the opposite is true for the states of Bavaria, Bremen, Hamburg, Hessen, Lower Saxony, and North-Rhine Westphalia. On average, $36.1 \%$ of visible minority deputies at the state level are women. Even though this number is slightly higher than that for the rest of women $(31.2 \%)$, it is fair to say they overall are underrepresented (table 2).

Table 2 Share of women and visible minorities in German Parliaments (March 2019)

\begin{tabular}{|c|c|c|c|}
\hline & $\begin{array}{c}\text { Share of visible } \\
\text { minorities ( } \% \text { and } \\
\text { absolute number) }\end{array}$ & $\begin{array}{c}\text { Share of women } \\
\text { among visible } \\
\text { minorities (\%) }\end{array}$ & $\begin{array}{l}\text { Share of women } \\
\text { among non- } \\
\text { minority deputies } \\
(\%)\end{array}$ \\
\hline Bundestag & $3.10 \quad(22)$ & 59.09 & 30.42 \\
\hline State parliaments & $3.26 \quad(61)$ & 36.07 & 31.18 \\
\hline Brandenburg & $0.00 \quad(0)$ & 0.00 & 39.77 \\
\hline Mecklenburg-Hither Pomerania & $0.00 \quad(0)$ & 0.00 & 25.35 \\
\hline Saxony & $0.00 \quad(0)$ & 0.00 & 33.33 \\
\hline Saxony-Anhalt & $0.00 \quad(0)$ & 0.00 & 21.84 \\
\hline Thuringia & $0.00 \quad(0)$ & 0.00 & 41.76 \\
\hline Saarland & $0.00 \quad(0)$ & 0.00 & 33.33 \\
\hline Lower Saxony & $2.19 \quad(3)$ & 0.00 & 31.34 \\
\hline Hessen & $5.11 \quad(7)$ & 14.29 & 34.62 \\
\hline North Rhine-Westphalia & $2.51 \quad(5)$ & 20.00 & 26.80 \\
\hline Bavaria & $1.95 \quad(4)$ & 25.00 & 26.87 \\
\hline Bremen & $18.07 \quad(15)$ & 26.67 & 39.71 \\
\hline Hamburg & $9.92 \quad(12)$ & 33.33 & 38.53 \\
\hline Berlin & $5.00 \quad(8)$ & 62.50 & 31.58 \\
\hline Baden-Wuerttemberg & $2.10 \quad(3)$ & 66.67 & 25.71 \\
\hline Rhineland-Palatinate & $0.99 \quad(1)$ & 100.00 & 31.00 \\
\hline Schleswig-Holstein & $4.11 \quad(3)$ & 100.00 & 27.14 \\
\hline
\end{tabular}

Sources: Websites of the federal and 16 state parliaments (1 March 2019)

In addition to geographical variation, there is also some historical variation. At the national level, for instance, the better representation of visible minority women compared to visible minority men is a rather new phenomenon. After the previous three elections, fewer visible 
minority women than men reached a mandate (after the 2013 elections, $44.4 \%$ of visible minority representatives were female, $30 \%$ after the 2009 elections, and $42.9 \%$ in 2005). At the state level, gender imbalances among visible minorities varied over the past three elections in Rhineland-Palatine, Lower Saxony, Hessen and Berlin. In the other states, tendencies have been more stable, that is, over the past three elections there have always been either a female (Schleswig-Holstein, Baden-Wuerttemberg) or a male majority (Hamburg, Bremen, NorthRhine Westphalia, Bavaria) among visible minority deputies.

Previous research has primarily focused on the question of why migrant women tend to be better represented than non-minority women and minority men. The question of what explains variation in the descriptive representation of visible minority women between states and legislative periods, by contrast, has largely been ignored. Even though I cannot conclusively resolve this intersectional puzzle because minority representation in Germany is a phenomenon too new and involving too low numbers for conducting a reliable time series analysis, the remainder of this article nevertheless discusses four possible explanations: (1) the political effects of institutional rules, such as gender quotas and electoral systems; (2) party politics and (3) demographics; as well as (4) informal practices of party elites.

\section{The political effects of institutional rules}

\section{A dual quota?}

In Germany, gender quotas have helped to increase the share of women in politics (DavidsonSchmich 2016). There is no legislated gender quota, but most political parties have introduced voluntary party quotas, ranging from a weaker quorum of $33 \%$ (CDU, since 1996) to stricter gender quotas of 40\% (SPD, since 1998, increased from 33\% introduced in 1988; CSU since 2010) and 50\% (Greens and The Left since their foundation in 1979 and 2007, respectively). 
The only relevant parties with no gender quotas are the liberal FDP and the new right-wing AfD, whose share of women in parliamentary groups and leadership bodies accordingly is much lower than in the other parties. Unlike for women, there is no immigrant quota, despite repeated calls for a formal electoral quota due to the continuous underrepresentation of immigrants in German politics (Peters 2018; Stuttgarter Zeitung 2007; Tagesspiegel 2017; Tank 2017; TAZ 2004). ${ }^{10}$

The female majority among visible minority representatives at the federal level and in several states suggests that political parties in Germany specifically promote visible minority women to 'kill two birds with one stone'. Nominating minority women satisfies not only the gender quota but also public demands for more diversity on party lists with just one person. Some scholars, therefore, assume that German parties, particularly those from the centre-left, practice an informal 'dual quota' for immigrant-origin women (Donovan 2013, 35; Hossain et al. 2016, 182ff; Markowis 2015; Wüst 2014).

An examination of the candidate lists for the 2017 general election (Bundeswahlleiter 2017), confirms this preference for minority women, but only in the case of winnable seats. When considering all candidates, the picture looks different. Of the seven parties that entered the Bundestag (CDU/CSU, SPD, the Left, the Greens, FDP and AfD), only $3.1 \%$ of the direct candidates and $3.2 \%$ of the party-list candidates had a visible, non-European migration background. Of those candidates, less than half (48\% direct and $49 \%$ party list) were women, suggesting a slightly smaller preference for minority women than for minority men, but a much higher women's share than among all candidates of these seven parties (27.4\% of candidates in constituencies and $36.2 \%$ on party lists were women). Taken together, only the SPD, the Greens and the AfD nominated more female minority candidates than male ones, while the Left, the CDU and the FDP selected more male minority candidates than female ones (the CSU

\footnotetext{
${ }^{10}$ In 2011, the SPD introduced an internal 15\% immigrant quota for party bodies (ZEIT Online 2011).
} 
none). In total, there were also more minority men (22) compared to minority women (19) who ran both in a constituency and on a regional party list, thus duplicating their chances to be elected. Of the 56 direct candidates ( 29 men and 27 women), most were nominated by the SPD, the Greens and the Left. But only the SPD and the Greens (and the AfD) had more women than men among their minority candidates. The same applied to the regional party lists.

However, not all candidates have the same chances to be elected. Their prospects of success depend on where they are placed on party lists and in which constituencies. When considering only candidates running in (relatively) secure constituencies and on (relatively) secure places on party lists, ${ }^{11}$ the picture changes. In only five of the 299 constituencies, parties nominated minority candidates for winnable constituency seats: three women (two representing the SPD, one the Greens) and two men (both SPD). On regional party lists, 17 minority candidates occupied promising places: 11 of them women, six men. In the latter case, all parties that selected minority candidates for promising places on their lists (SPD, Left, Greens and CDU) preferred women over men (except for the Greens, which nominated one man more).

The data demonstrate that political parties in Germany, especially from the centre-right spectrum, are still very hesitant to nominate minority candidates for promising seats, both men and women. In the centre-left parties, by contrast, minority women benefit from a quota-driven 'elevator effect', which helps to 'promote the limited women present to positions of authority within the party' (Davidson-Schmich 2016, 16). Overall, however, visible minority candidates are primarily selected for less promising seats, and then often more men than women. Beyond other possible reasons, such as an incumbency effect (Reiser 2014), this provides parties with the opportunity to give the appearance of being supportive of diversity without risking winnable seats for non-minority candidates. The main reasons for the preference of minority

\footnotetext{
${ }^{11}$ Based on which party held the constituency in the two previous elections (2009 and 2013) and on the number of seats reached in the previous election (2013).
} 
women over minority men at the national level when winnable seats are concerned are not entirely clear, but strategic considerations by party elites to maximise the representativeness of their party lists (Celis and Erzeel 2017) and the gender quota certainly are central among them. The preference of party elites to nominate minority women over minority men was also confirmed in my interviews with female politicians with a visible migration background. Some of the interviewed representatives from the Green and Left parties reported about an informal 'multiple quota' (interview 1) which they benefitted from in the nomination process. Such an informal 'dual quota', however, is a 'double-edged sword' (interview 12). On the positive side, it assists visible minority women in their political careers. On the other hand, it does not necessarily increase equal opportunities because nominating one person to meet two 'quotas' allows parties 'to appear more inclusive while still conserving a maximum number of opportunities for white men’ (Murray 2016, 595; see also Hossain et al. 2016, 185).

Unsurprisingly, the interviewed female politicians of a visible migration background, though mostly supportive of the gender quota, were divided about the question of immigrant quotas. Whereas some of them would favour the introduction of a formal immigrant quota to increase the number of immigrants in political office, others were more sceptical, raising concerns about the risk of a proliferation of quotas (not only on grounds of gender and migration background, but also age, disability, religion, first- and second-generation immigrant, world regions, etc.). In addition to already existing informal selection rules and quotas (e.g., incumbents, region. See Reiser 2014), this would make the candidate recruitment process too complicated.

Moreover, some interviewees expressed the prevailing view that quotas decreased the quality of the candidates recruited, which in their view carries the risk of counterproductive confirmation of public stereotypes about members of immigrant groups. In the end, this would turn out to be worse for minority representation. Finally, an immigrant quota would turn candidates into 'token migrants' (interview 12) and support candidates who rely on their 
immigrant status, for example, as 'professional Turks' (interview 6), overemphasising migration background at the expense of performance. Therefore, other instruments, such as comprehensive mentoring programmes, specific targeting and the appointment or election of intra-party representatives for diversity would be preferred by most of the interviewed politicians over the introduction of a formal immigrant quota.

In sum, the election data do indeed confirm that German political parties often prefer to nominate minority women over minority men, at least when winnable seats at the national level are concerned, explaining why the representation of women among visible minority representatives often is better than that of visible minority men. However, formal gender quotas (often in combination with informal attempts to increase diversity) cannot explain the variation in minority women's and men's representation in different German states, as these quotas are in force across the whole of Germany. To explain this variation, other factors must be considered.

\section{Electoral systems}

In most German states, the electoral system resembles the federal system: personalised proportional representation. However, there are a few states that employ distinctive election rules, ${ }^{12}$ such as Baden-Wuerttemberg and the two city-states Hamburg and Bremen. Due to a lack of party lists, the Baden-Wuerttemberg system resembles a majority system. Accordingly, the state has had notably low shares of women and immigrants in its parliament. In Hamburg and Bremen, the personalised element was abolished, and proportional representation with open lists was introduced. The existence of personal votes (five in Bremen and 10 in Hamburg) and less competition for seats ${ }^{13}$, in combination with urban culture, have arguably contributed

\footnotetext{
${ }^{12}$ For an overview of German state electoral systems, see https://www.wahlrecht.de/landtage/.

${ }^{13}$ According to Schönwälder $(2013,644)$, it is much easier to become a member of parliament in a city-state than in a large territorial state, because the number of voters per seat is much lower. For instance, in North RhineWestphalia there are about four times as many votes required to win a seat than in Berlin.
} 
to higher shares of women and immigrants in the parliaments of the two city-states than most other German states (Schönwälder 2013, 644). Therefore, one would expect that the women's share among visible minority representatives would be decidedly low in Baden-Wuerttemberg and high in Hamburg and Bremen. However, the opposite is true. Over the past three elections, the majority of visible minority representatives in Baden-Wuerttemberg have been women, whereas in Hamburg and Bremen most have been men (see table 2 above). One possible explanation for this counterintuitive finding is that open list systems can be unfavourable for minority women if voters are less inclined to give their votes to female candidates. This may be the case if male visible minority candidates with more resources and better networks at their disposal than visible minority women specifically mobilise for personal votes within immigrant communities in which patriarchal attitudes prevail. This possible disadvantage of open-list systems is also confirmed in Bavaria - the only territorial state in which open lists are used and where more visible minority men than women have been elected in the past three elections. However, these differences in electoral systems do not explain why, for instance, the minority of visible minority women at the federal level turned into a majority after the last general election or why in some states, such as Schleswig-Holstein and Berlin, visible minority women are usually better represented than their male counterparts, whereas in many other states the opposite is the case, despite similar electoral systems. Therefore, I also examined two other possible explanations: the electoral success of political parties and the ethnic density in German states.

\section{Party politics and demographics}

Following up on the discussion of quotas above, one could expect that visible minority women are better represented in states with a centre-left majority because those parties are traditionally more supportive of gender quotas and responsive to calls for diversity. However, when 
computing the share of women among visible minority representatives against the share of centre-left parliamentary seats, no correlation appears $(\mathrm{r}=-0.02)$ (figure 1$)$.

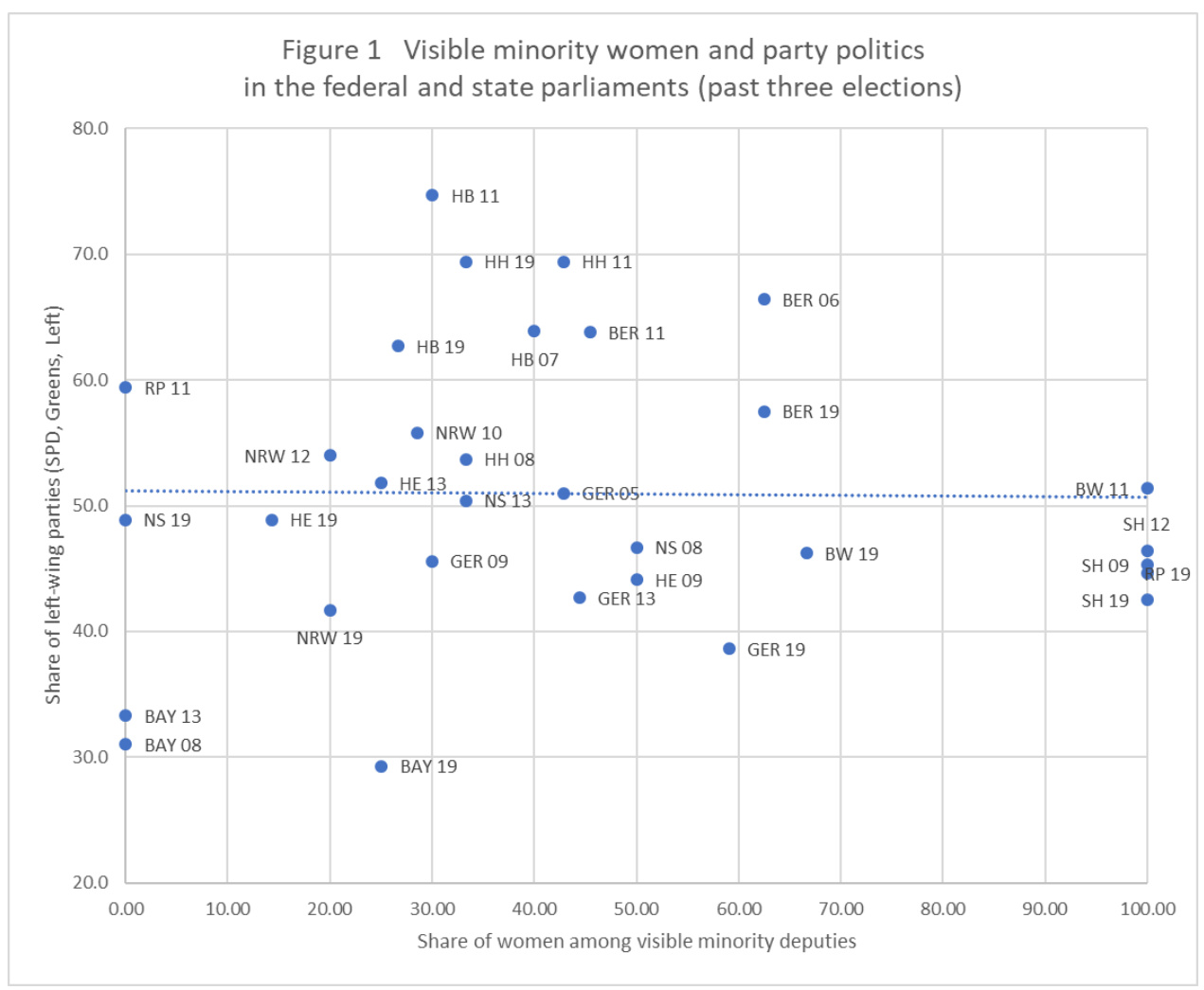

Similarly, the explanatory power of demographics for the variation between states in the proportion of women among immigrant parliamentarians is weak $(r=-0.23)$. A higher density of populations with a migration background may explain why the pool of potential candidates is more extensive and thus more immigrants are represented in parliaments, but it cannot explain why there are more women among visible minorities in some state parliaments than in others (figure 2). 


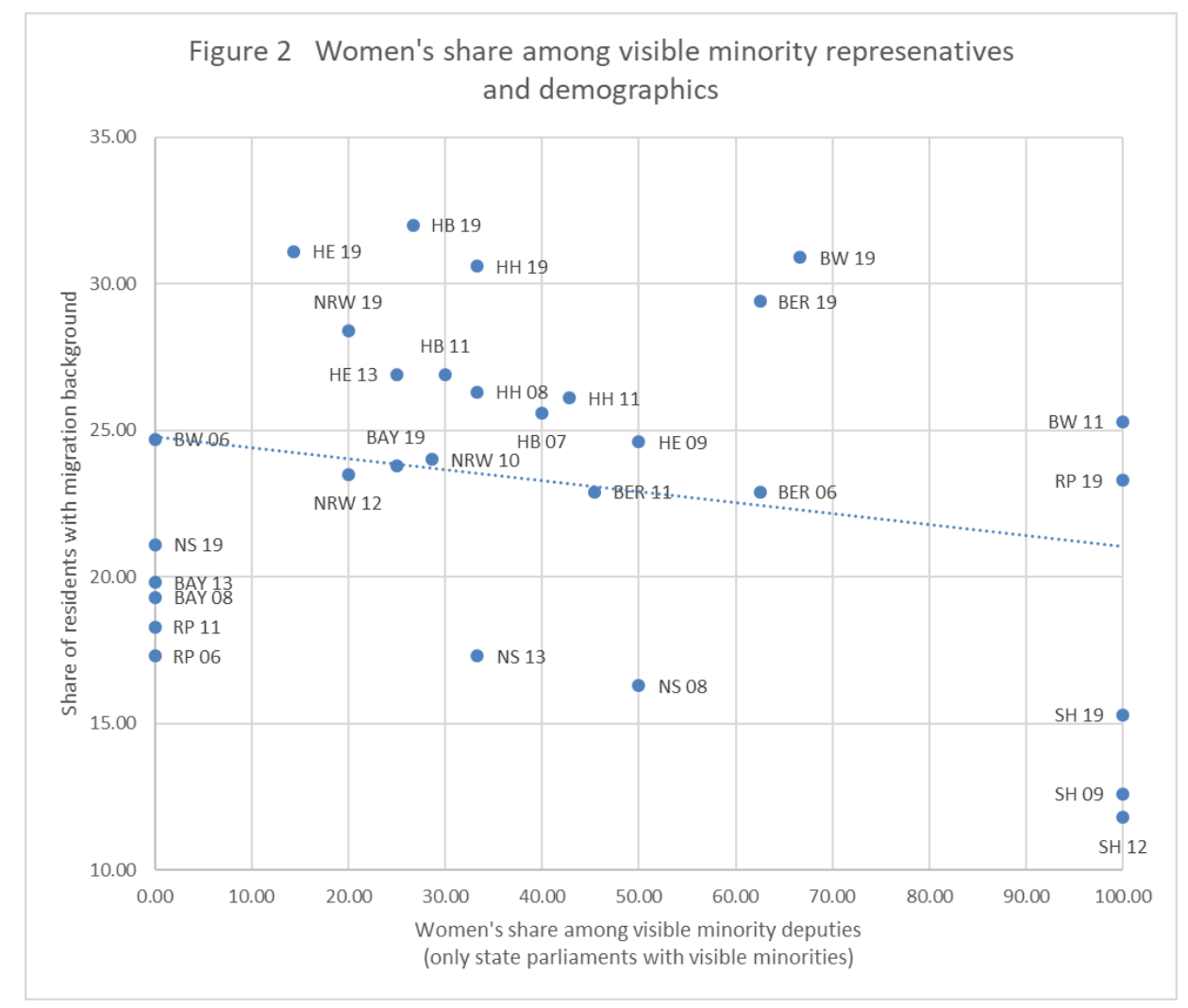

\section{The political effects of informal practices}

If formal institutional rules such as quotas and electoral systems provide only part of the explanation for variation in visible minority women representation between states, and party politics and demographics do not have any explanatory power at all, questions remain about the causes of the variation. The interviews I conducted with minority women politicians in Germany suggest that informal practices by local party organisations and party elites play a crucial role. These practices range from discrimination and disregard, which foster exclusion, to targeted recruitment and support, which facilitate inclusion.

Exclusionary practices experienced by the interviewed female politicians include difficulties accessing local party organisations. Access appears to be easier in the case of small parties such as the Greens and the Left, which are characterised by open party structures. In the larger parties, such as CDU and SPD, access can be difficult. Some of the interviewees reported about changing their local party organisation because they did not receive any support in the previous 
one. Others mentioned initial problems, also in the smaller parties, because they were not taken seriously as young women with a migration background. The interviews make clear that a welcoming culture and intercultural sensibility on the part of local party organisations is essential. If reservations against immigrants or (young) women exist, it is difficult to get access to the party, informal networks and local leadership positions vital for a political career. According to the interviewees' experiences, personal contacts through friends or networks in the volunteer sector are beneficial for access to parties or parties may directly recruit potential or dormant visible minority members to become active, for instance, through personalised letters.

Other exclusionary practices observed by interviewed politicians referred to the nomination process. Individuals, for example, have mobilised against the nomination of immigrant candidates whose political positions, for instance, on religion, met resistance within local party organisations.

Accordingly, the views on the aforementioned informal 'dual quota' diverge. While some interviewees, as explained above, had the impression that their parties (primarily left: Greens and the Left) employ an informal 'dual quota', others, in this case from the SPD, think that preferential treatment of minority women is public perception rather than reality within parties:

That is perceived like that anyway, that we take advantage of our migration background, because allegedly people somehow want to use us to demonstrate their diversity. But I have not really realised, or I have not regarded it as such, that I, due to my migration background, have been considered a positive example anywhere (interview 13).

Several of the interviewed women pointed out that a migration background is only selectively considered by parties, including the left-leaning parties, and that parties must constantly be reminded to create diverse party lists as otherwise that would not happen. One respondent criticised the discrimination against non-native speakers. To counter exclusion, two of the 
interviewees, after being skipped several times, felt forced to 'draw the immigrant card' (interviews 4 and 11) to make their way onto party lists or into official party bodies, even though they did not like doing that.

Some of the interviewed politicians (from different parties on the spectrum) experienced a current backlash against diversity. They criticise that it had been popular for some time to promote diversity in German politics but that, due to the current political dynamics, this has gone out of fashion, as one of the interviewees states: 'At the moment, it is not hip anymore to promote migrants. Now, everybody runs after the AfD' (interview 9). Particularly in the CDU/CSU, the number of immigrants and Muslims in the party's parliamentary groups at the federal and state level, as well as in its management boards, has decreased considerably, and active measures to address this issue are not visible (Dernbach and Sirleschtov 2018). This backlash has also been noted by members of more left-leaning parties.

Such exclusionary practices are countered by stories of inclusionary experiences of individual support from party leadership. The political biographies of the interviewed minority women reveal that almost all interviewees who successfully achieved a mandate benefitted from targeted recruitment and received specific support from party elites. They were directly approached to recruit them as party members, to assume intraparty offices or to become a candidate for elections. In many cases, minority women candidates were not expected to bring along the many years of experience within party structures usually required, and sometimes they were moved from a less supportive local party organisation to a more supportive one. In contrast, female minority politicians who have not been nominated for elections, or only in unpromising places, often criticise the lack of internal party support, perceiving themselves as outsiders. Visible minority politicians felt excluded not only due to their migration background but also for other cultural reasons, such as a lack of socialisation within the party's youth organisation or their religious background. 
Like 'dual quotas', targeted recruitment, however, cuts both ways. On the one hand, it supports individual visible minority women in their political careers, thus contributing to increasing equality and diversity in German politics. On the other hand, it enables political parties to preserve their roles as gatekeepers. Party elites decide themselves which women they support. This can result in access for a specific group and exclusion of other groups, for example, Muslim women wearing the Islamic headscarf. These individualised practices, moreover, enable political parties to subdue criticism from within. Research identifies discrimination by parties in the ranking process of women and immigrants on candidate lists as the primary explanation of why these groups are still underrepresented (Davidson-Schmich and Kürschner 2011; Holtkamp, Schnittke, and Wiechmann 2011; Hossain et al. 2016, 178ff). However, little has been done to make these discriminatory practices a subject of discussion within parties, leading to the reproduction of disadvantages for women and immigrants (Hossain et al. 2016, 149). Among minority politicians who hold a mandate, targeted recruitment generates a feeling of being supported - which also became visible in my interviews - and thus obscures practices of discrimination.

Ultimately, idiosyncratic practices by party elites are arbitrary because they are individualised, which does not only prevent a more systematic approach to promote visible minority representation, it also helps explain why there is variation in how visible minority women and men are represented.

\section{Conclusions}

Germany's federal system is a fascinating laboratory for studying the political representation of women and minorities. Analysing why in some German states visible minority women outnumber their male counterparts, while in other states the reverse situation can be found, allows for exploration of factors that support visible minority women to successfully run for 
office and obstacles preventing them from doing so. This study supports findings of previous research demonstrating that gender quotas and closed party lists in representative electoral systems are conducive to the political representation of visible minority women. However, these explanations can only provide part of the answer to the intersectional puzzle of varying representation. Experiences of the interviewed visible minority women in German politics suggest that the selective promotion of visible minority women by individual party elites is another contributing factor. Party elites serve as important gatekeepers in intra-party recruitment and nomination processes. Depending on their preferences, individual party elites either support visible minority women or they overlook or even discriminate against them, resulting in different levels of support for individual candidates, thus contributing to varying levels of representation.

This finding supports earlier intersectional research on immigrants in German politics, which suggests that minority women benefit from gender quotas and that, at the same time, the (selective) discrimination by party elites remains a significant factor in the explanation of underrepresentation of both women and immigrants in German politics (Hossain et al. 2016; Markowis 2015; Wüst 2014). However, rather than focusing either on supportive formal institutional rules or on discriminatory informal practices, this analysis stresses that informal practices can go both ways and are mediated by individual attitudes and preferences as well as institutional rules.

It can be assumed that this ambivalent situation between discrimination and support not only applies to visible minority women but also to minority men. Depending on their attitudes and stereotypes regarding gender and ethnic diversity, party elites at different levels individually decide whom they choose to support (or ignore, or even actively prevent). In combination with the incentive of gender quotas and mediated by the electoral system, this leads to varying levels of support for individuals from different groups. However, more research is necessary to 
corroborate this finding, particularly on the experiences of visible minority men and the practices of party gatekeepers concerning their selections of particular candidates (Bjarnegård and Kenny 2016, 376). Further potential explanations could be scrutinised, such as the role of intraparty mentoring programmes which may vary between German states. The resulting information would allow parties to tackle bias among party elites and to optimise the promotion of disadvantaged groups within their party structures in a more targeted way to finally make equal representation a reality in German politics.

\section{References}

Bird, Karen. 2014. "Ethnic Quotas and Ethnic Representation Worldwide." International Political Science Review 35 (1): 12-26.

Bird, Karen. 2016. "Intersections of Exclusion: The Institutional Dynamics of Combined Gender and Ethnic Quota Systems.” Politics, Groups, and Identities 4 (2): 284-306.

Bird, Karen, Thomas Saalfeld, and Andreas M. Wüst. 2011. "Ethnic Diversity, Political Participation and Representation: A Theoretical Framework." In The Political Representation of Immigrants and Minorities. Voters, Parties and Parliaments in Liberal Democracies, edited by Karen Bird, Thomas Saalfeld, and Andreas M. Wüst, 1-21. London: Routledge.

Bjarnegård, Elin. 2013. Gender, Informal Institutions and Political Recruitment: Explaining Male Dominance in Parliamentary Representation. Basingstoke: Palgrave Macmillan. Bjarnegård, Elin, and Meryl Kenny. 2016. "Comparing Candidate Selection: A Feminist Institutionalist Approach.” Government and Opposition 51 (3): 370-392. 
Bloemraad, Irene, and Karen Schönwälder. 2013. "Immigrant and Ethnic Minority Representation in Europe: Conceptual Challenges and Theoretical Approaches.” West European Politics 36 (3): 564-579.

Bundesamt für Familie, Senioren, Frauen und Jugend (BMFSFJ). 2017. 3. Atlas zur Gleichstellung von Frauen und Männern in Deutschland. https://www.bmfsfj.de/bmfsfj/service/publikationen/3--atlas-zur-gleichstellung-vonfrauen-und-maennern-in-deutschland/114010

Bundeswahlleiter. 2017. "Wahl zum 19. Deutschen Bundestag am 24. September 2017, Sonderheft Wahlbewerber: Die Wahlbewerberinnen und Wahlbewerber für die Wahl zum 19. Deutschen Bundestag." Informationen des Bundeswahlleiters. Wiesbaden.

Celis, Karen, and Silvia Erzeel. 2017. "The Complementarity Advantage: Parties, Representativeness and Newcomers' Access to Power.” Parliamentary Affairs 70 (1): 43-61.

Celis, Karen, Silvia Erzeel, Liza Mügge, and Alyt Damstra. 2014. "Quotas and Intersectionality: Ethnicity and Gender in Candidate Selection.” International Political Science Review 35 (1): 41-54.

Davidson-Schmich, Louise K. 2016. Gender Quotas and Democratic Participation: Recruiting Candidates for Elective Offices in Germany. Ann Arbor: University of Michigan Press. Davidson-Schmich, Louise K., and Isabelle Kürschner. 2011. "Stößt die Frauenquote an ihre Grenzen? Eine Untersuchung der Bundestagswahl 2009.” Zeitschrift für Parlamentsfragen 42 (1): 25-34.

Dernbach, Andrea and Antje Sirleschtov. 2018. “Zur CDU gehört nur ein bisschen Islam.” Der Tagesspiegel, April 5. https://www.tagesspiegel.de/politik/muslimischechristdemokraten-zur-cdu-gehoert-nur-ein-bisschen-islam/21141826.html 
Donovan, Barbara. 2013. "Intersectionality and the Substantive Representation of Migrant Interests in Germany." German Politics and Society 30 (4): 23-44.

Fernandes, Jorge, Laura Morales, and Thomas Saalfeld. 2016. "Pathways to Power: The Political Representation of Citizens of Immigrant Origin in Eight European Democracies. Report on Preliminary Findings.” http://pathways.eu/wpcontent/uploads/2016/02/Pathways-to-power-leaflet-FINAL.pdf

Freidenvall, Lenita. 2016. "Intersectionality and Candidate Selection in Sweden.” Politics 36 (4): 355-363.

Geese, Lucas, and Diana Schacht. 2019. “The more concentrated, the better represented? The geographical concentration of immigrants and their descriptive representation in the German mixed-member system.” International Political Science Review 40 (5): 643658.

Green, Simon. 2004. The Politics of Exclusion: Institutions and Immigration Policy in Contemporary Germany. Manchester, New York: Manchester University Press.

Hancock, Ange-Marie. 2007. “When Multiplication Doesn’t Equal Quick Addition: Examining Intersectionality as a Research Paradigm.” Perspectives on Politics 5 (1): 63-79.

Holtkamp, Lars, Sonja Schnittke, and Elke Wiechmann. 2011. "Die Stagnation der parlamentarischen Frauenrepräsentanz: Erklärungsansätze am Beispiel deutscher Großstädte." Zeitschrift für Parlamentsfragen 42 (1): 35-49.

Hossain, Nina, Caroline Friedhoff, Maria Funder, Lars Holtkamp, and Elke Wiechmann. 2016. Partizipation - Migration - Gender: Eine Studie über politische Partizipation und Repräsentation von Migrant_innen in Deutschland. Baden-Baden: Nomos.

Hughes, Melanie M. 2011. “Intersectionality, Quotas, and Minority Women's Political Representation Worldwide.” American Political Science Review 105 (3): 604-620. 
Hughes, Melanie M. 2016. "Electoral Systems and the Legislative Representation of Muslim Ethnic Minority Women in the West, 2000-2010.” Parliamentary Affairs 69 (3): 548568.

Krook, Mona Lena. 2010. Quotas for Women in Politics: Gender and Candidate Selection Reform Worldwide. Oxford, New York: Oxford University Press.

Krook, Mona Lena, and Pippa Norris. 2014. "Beyond Quotas. Strategies to Promote Gender Equality in Elected Office.” Political Studies 62 (1): 2-20.

Lang, Sabine. 2015. “Thirty Years of Gender Quotas in Germany: Policy Adoption between Mainstreaming and Minimal Compliance.” EUI Working Papers, Law 2015/21. European University Institute: Florence.

Markowis, Freya A. 2015. Mandatsträgerinnen und Mandatsträger mit Migrationshintergrund: Karrierewege und substantielle Repräsentation von Landtagsabgeordneten mit Zuwanderungsgeschichte. Berlin: LIT Verlag.

Mügge, Liza M., and Silvia Erzeel. 2016. "Double Jeopardy or Multiple Advantage? Intersectionality and Political Representation.” Parliamentary Affairs 69 (3): 499-511.

Mügge, Liza M., Celeste Montoya, Akwugo Emejulu, and S. Laurel Weldon. 2018. "Intersectionality and the politics of knowledge production." European Journal of Politics and Gender 1 (1-2): 17-36.

Murray, Rainbow. 2016. "The Political Representation of Ethnic Minority Women in France." Parliamentary Affairs 69 (3): 586-602.

Norris, Pippa. 2006. “The Impact of Electoral Reform on Women's Representation.” Acta Politica 41 (2): 197-213.

Paxton, Pamela, Sheri Kunovich, and Melanie M. Hughes. 2007. "Gender in Politics.” Annual Review of Sociology 33: 263-284. 
Peters, Benedikt. 2018. "Migrationshintergrund: Der Bundestag braucht eine Quote." Süddeutsche Zeitung, August 1. https://www.sueddeutsche.de/politik/migrationmikrozensus-kommentar-1.4077485

Reiser, Marion. 2014. "The Universe of Group Representation in Germany: Analysing Formal and Informal Party Rules and Quotas in the Process of Candidate Selection.” International Political Science Review 35 (1): 55-66.

Schönwälder, Karen. 2010. "Einwanderer in Räten and Parlamenten." Aus Politik und Zeitgeschichte 46-47: 29-35.

Schönwälder, Karen. 2013. “Immigrant Representation in Germany’s Regional States: The Puzzle of Uneven Dynamics.” West European Politics 36 (3): 634-651.

Schönwälder, Karen, Cihan Sinanoglu, and Daniel Volkert. 2011. Vielfalt sucht Rat: Ratsmitglieder mit Migrationshintergrund in deutschen Großstädten. Berlin: Heinrich Böll Stiftung.

Statistisches Bundesamt. 2018. Bevölkerung und Erwerbstätigkeit: Bevölkerung mit Migrationshintergrund-Ergebnisse des Mikrozensus 2017. https://www.destatis.de/DE/Publikationen/Thematisch/Bevoelkerung/MigrationIntegr ation/Migrationshintergrund2010220177004.pdf?_blob=publicationFile

Stuttgarter Zeitung. 2007. "Quote für Migranten in Parteien gefordert: Türkischstämmige Mandatsträger beklagen mangelnde Beteiligung in der Politik.” July 17.

Tagesspiegel. 2017. “Türkische Gemeinde fordert Migrantenquote.” September 8.

Tank, Gün. 2017. "Mehr Migranten in den Bundestag!" ZEIT Online, September 21. https://www.zeit.de/gesellschaft/zeitgeschehen/2017-09/migration-deutschlandmigrantenquote-neue-deutsche-organisationen

TAZ. 2004. "Migrantenquote fürs Rathaus.” January 14. 
Weldon, S. Laurel. 2006. "The Structure of Intersectionality: A Comparative Politics of Gender." Politics \& Gender 2 (2): 235-248.

Wüst, Andreas M. 2014. "Immigration into Politics: Immigrant-origin Candidates and Their Success in the 2013 Bundestag Election." German Politics and Society 32 (3): 1-15.

Wüst, Andreas M. 2016. "Incorporation beyond Cleavages? Parties, Candidates and Germany’s Immigrant-Origin Electorate” German Politics 25 (3): 414-432.

Wüst, Andreas M., and Thomas Saalfeld. 2011. “Abgeordnete mit Migrationshintergrund im Vereinigten Königreich, Frankreich, Deutschland und Schweden: Opportunitäten und Politikschwerpunkte.” In Politik als Beruf, edited by Michael Edinger and Werner J. Patzelt, 312-333. PVS - Politische Vierteljahrsschrift, Sonderheft 44/2010, VS Verlag.

ZEIT Online. 2011. "Integrationsdebatte: SPD plant parteiinterne Migrantenquote.” May 2. https://www.zeit.de/politik/deutschland/2011-05/spd-migrantenquote-sarrazin 